\title{
Economics and Bussiness
}

Volume 1, Number 1, June 2018

http://journals.ums.ac.id/index.php/mijeb

\section{THE ANALYSIS OF REVENUE SHARING FROM MUDHARABAH FINANCING (Case Study of BMT AL FATH IKMI CIPUTAT)}

\author{
Mega Rosdiana \\ Fakultas Ekonomi dan Binis Universitas Muhammadiyah Jakarta \\ Siti Jamilah \\ Fakultas Ekonomi dan Binis Universitas Muhammadiyah Jakarta \\ Email: jamilah.febumj@gmail.com \\ Andry Priharta \\ Fakultas Ekonomi dan Binis Universitas Muhammadiyah Jakarta \\ Email: andrypriharta@yahoo.co.id
}

\begin{abstract}
The purpose of this study is to determine the effect of revenue sharing from mudharabah financing at BMT AL-Fath Ikmi Ciputat. Mudharabah is a business cooperation agreement between two parties where the first party (shahibul maal) provides the whole (100\%) capital, while the other party becomes the manager. The margin is the amount of profit agreed between BMT and the customer on the financing transaction with the sale and purchase agreement, in which margins remain unchanged over the term of the financing. This study is quantitative research, which aims to give description about the subject under study and check the truth of the research result, by using descriptive verification method. The samples are taken using data collection techniques and are documented by collecting financial statement data. The data processing methods use classical assumption test and simple linear regression analysis. Then the conclusion of the result of calculation of statistic test $t$ partial known $t_{\text {count }}<t_{\text {table }},(2.165>2.0322)$ with significant value from mudharabah financing variable equal to 0.0042 less than 0.05 or $5 \%$ and have positive coefficient direction. It can be concluded that Ho is rejected and Ha accepted, which means that mudharabah financing variables have significant and positive effect on profit sharing.
\end{abstract}

\section{Keywords: Profit Sharing and Mudharabah Financing}

\section{Introduction}

In Indonesia there have been many efforts made by the community from medium to small business. According to Central Bureau of Statistics, Business Tendency Index or Indeks Tendensi Bisnis (ITB) is an indicator of the current economic development, in which the data are obtained from the Business Tendency Survey Survei Tendensi Bisnis (STB) conducted by the Central Bureau of Statistics in cooperation with Bank Indonesia. STB is conducted quarterly in selected major cities across the province in Indonesia. The number of
STB samples in quarter III-2016 was 5074 large and medium enterprises, and the respondents are the corporate leaders. ITB is an index that describes the business and economic condition in the current quarter and forecast the upcoming quarter.

The development of medium- and small-sized enterprises is growing due to a factor, which is the capital of a company itself. Nowadays in Indonesia there are many conventional banks that open their own business units by following sharia law, such as Bank Syariah Mandiri, Bank BTN Syariah and the emergence of sharia non-bank financial institutions 
such as sharia cooperatives, BMT, Takaful Insurance, institutions dealing with zakat such as LAZIS, BAZIS, and dompet Dhuafa. The sharia banks and other institutions require sharia products in running its operations, which are certainly in accordance with the sharia laws and free from usury. Unlike conventional banking, in sharia banking there is no interest; rather, it uses profit sharing, which means division of profit (Ridwan, 2011). In the Islamic finance, the mechanism of profit-sharing model relates to fund raising (funding) or channeling of funds or financing (Ridwan, 2011).

Based on the Fatwa of the National Sharia Council or Dewan Syariah Nasional (DSN) Number: 15 / DSN-MUI / IX / 2000 on the principle of distribution of business profit in sharia financial institutions, the distribution of business profit between the parties (partners) in a form of business may be based on principles. First, for profit sharing, in which profit sharing is calculated from income after deducting fund management cost, and may also be based on principle. Second, revenue sharing, which is the revenue share calculated from the total revenue of fund management and each has advantages and disadvantages.

In Islamic financial system and Baitul Maal wat Tamwil (BMT), the profit-sharing model applies only to the contract of business participation or business cooperation. This agreement can be applied in four products; namely, mudharabah, musyarakah, muzara'ah, and musaqoh. Technically, mudharabah is a business cooperation contract between two parties where the first party (shahibul maal) provides all the capital, while the other party becomes the manager. This form affirms cooperation in the alloy of $100 \%$ cash capital from shahibul maal and expertise from mudharib, with the previously agreed ratio of profit sharing. In mudharabah, mudharib served as a trustee, $\mathrm{s} / \mathrm{h}$ is required to act cautiously and be responsible for the possibility of loss caused by his negligence. Mudharib is expected to use and manage capital in such a way as to generate optimal profit for businesses that are run without violating Islamic sharia values.

Margin is the amount of profit agreed between BMT and the customer on the financing transaction during the sale and purchase agreement (Muhammad Ridwan, 2011). Margin is fixed and unchanged throughout the financing period. It can be affected by several factors, namely: the amount of financing; the term of financing; the system of return; the amount of costs arising from the financing; the competition level of price in market, either with the similar and/ or conventional financial institutions; because the nature of this agreement is purchase, the standard profit is not limited. BMT is one of the financial institutions with a goal to increase and develop the potential of people in poverty alleviation, helping small entrepreneurs to obtain loan capital, and create sources of financing and capital provision for customers under the principles of sharia. There are many BMTs in Indonesia, one of them is BMT ALFATH IKMI CIPUTAT.

Based on the research background, there are several problems identified in this study:

1. Is there any significant influence of revenue sharing from mudharabah financing at BMT AL FATH IKMU ?

2. Does the effects of revenue-sharing income have a major impact on mudharabah financing?

\section{Literature Review \\ Definition of Baitul Maal Wat Tamwil (BMT)}

DR. Andri Soemitra, M.A. (2010: 451) defines BMT, which stands for Balai Usaha Mandiri Terpadu or Baitul Maal Wat Tamwil, as a microfinance institution (MFI) operating on the basis of Sharia principles. BMT, as the name implies, consists of two main functions, namely:

1) Baitul Tamwil (the house of wealth development), conducts productive business activities and investment activities to improve the economic quality of micro and small entrepreneurs by encouraging savings activities and supporting the financing of economic activities.

2) Baitul Maal (the house of wealth), receives zakat, infaq, and shadaqah, and optimizes its distribution according to the rules and its mandate.

BMT is subject to the rules of cooperatives, namely Undang-Undang No. 25 Tahun1992 tentang Koperasi, which was amended in Undang-Undang No. 17 Tahun 2012 tentang Koperasi. KEPMEN Nomor 91/KEP/M.KUKM/IX/2004 tentang Petunjuk Pelaksanaan Kegiatan Usaha Koperasi Jasa Keuangan Syariah (KJKS).

\section{Financing}

According to M.Syafi'i Antonio (2012: 160), financing is one of the main tasks of a bank, which is to provide funding to meet the needs of parties 
that are deficit units. Meanwhile, UU No. 10 tahun 1998 tentang Perbankan states that "Financing based on sharia principles is the provision of money or equivalent claims based on an agreement or contract between a bank or a financial institution with another party, which requires the financed party to refund the money or invoice after a certain period of time in revenue or profit sharing."

It is further explained in UU No. 21 tahun 2008 on sharia banking article 1 point 25 that financing is the provision of money or equivalent claims in the forms of:

a. Revenue sharing transaction in the form of mudharabah and musyarakah.

b. Lease transaction in the form of ijarah or lease purchase in the form of ijarah muntahiya bittamlik.

c. Sale and purchase transaction in the form of murabahah receivables, salam, and istishna.

d. Sale and purchase transaction in the form of qard receivables.

e. Lease transaction in the form of ijarah for multilateral transactions.

The financing based on revenue sharing principle is used for cooperative business aimed at obtaining goods and services, the product consists of:

\section{a. Musyarakah}

Musyarakah is partial financing of capital needs of a business for limited timeframe in accordance with the agreement.

\section{b. Mudharabah}

Mudharabah is a business cooperation agreement between two parties, in which the first party (shahibul maal) provides all capital, while the second party becomes the manager.

\section{Mudharabah \\ Definition of Mudharabah}

Adiwarman A. Karim (2013: 204) defines mudharabah as a form of contract between two parties, in which one party acts as the owner of the capital and entrusts a number of capital to be managed by a second party, which is the business executor, with the aim of gaining profit. Or simply, mudharabah is the agreement of partnership of a property between one party and another party for the labor.

DR. Mardani (2013: 165) defines mudharabah as a contract (agreement) between the owner of capital (rab al-mal) and the user of funds (mudharib) to be used for productive activities where profits are divided between investors and capital managers. Possible losses are borne by the owner of the capital, if the loss occurs under normal circumstances, the investor ( $\mathrm{rab}$ al-mal) may not intervene how the fund user (mudharib) runs his business.

In general, mudharabah is divided into two types: mudharabah muthlaqah and mudharabah muqayyadah.

a. Mudharabah muthlaqah

Mudharabah muthlaqah is a form of partnership between shahib al-mal and mudharib with wider scope and is not limited by the specification of business type, time, and business area. In the discussion of fiqh scholars, Salafus Saleh, it is often exemplified by the expression if'al maa syita (do as you please) from shahib al-mal which gives huge authority for the business owner.

b. Mudharabah muqayyadah

Mudharabah muqayyadah, is the opposite of mudharabah muthlaqah. Mudharib is limited by certain limits such as type of business, time, or place of business. This restriction often reflects the general trend applied by shahib almall in entering the world of business.

The legal foundation of mudharabah financing is contained in Fatwa DSN No.07/DSN-MUI/ IV/2000 on Mudharabah Financing (Qiradh). In the First Dictum on the terms of financing, they are mentioned as follows:

a. Mudharabah financing is a financing channeled by LKS to other parties for productive business.

b. In this financing, LKS as shahibul maal (owner of fund) $100 \%$ finances various needs of a project (business), while the entrepreneur (customer) acts as mudharib or business manager.

c. The business period, the procedure for refunds, and the distribution of profits are determined based on the agreement of both parties (LKS with employers).

d. Mudharib may carry out various types of business that have been mutually agreed upon and in accordance with the sharia; and LKS does not participate in company or project management, but has the right to conduct guidance and supervision.

e. The amount of financing funds must be clearly stated in cash and non-receivable. 
f. LKS as the provider of funds shall bear all losses resulting from mudharabah, unless mudharib (customer) makes deliberate and/or negligent mistake or if there is a breach of the agreement.

g. In principle, in mudharabah financing, there is no guarantee, but in order to prevent mudharib from violating contract, LKS may request guarantees from mudharib or third party. This guarantee can only disbursed if mudharib is proven to have violated the points agreed upon in the contract.

h. Employers' criteria, financing procedures, and profit sharing mechanism are regulated by LKS by adhering to DSN Fatwa.

i. $\quad$ Operational costs are charged to mudharib.

j. In the event of provider of fund (LKS) is not liable or commit a breach of agreement, mudharib shall be entitled to compensation or incurred expenses.

\section{Scheme of Mudharabah}

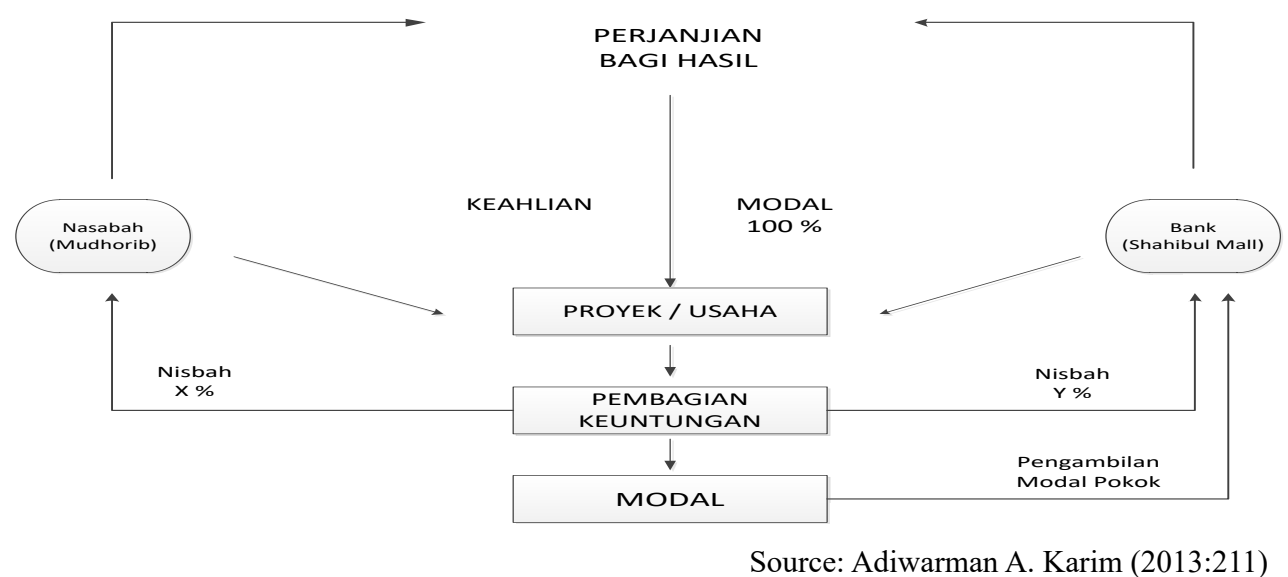

Figure 2.1. Scheme of Mudharabah

Findings and Discussion

Analysis of Development of Mudharabah Financing

The data used in this analysis are obtained from the monthly financial statements of BMT
Al-Fath Ikmi Ciputat. In the following table, the researchers will present data on mudharabah financing for the last three years from 2014 to 2016.

Table 1. Mudharabah Financing at BMT Al-Fath Ciputat

in 2014-2016 (in IDR)

\begin{tabular}{|c|c|c|c|}
\hline Month & 2016 & 2015 & 2014 \\
\hline January & 420.900 .000 & 724.350 .000 & 72.633 .600 \\
\hline February & 365.200 .000 & 664.350 .000 & 321.933 .600 \\
\hline March & 565.000 .000 & 644.350 .000 & 476.468 .600 \\
\hline April & 562.300 .000 & 610.050 .000 & 566.318 .600 \\
\hline Mei & 525.500 .000 & 498.075 .000 & 566.318 .600 \\
\hline June & 524.000 .000 & 372.650 .000 & 501.318 .600 \\
\hline July & 524.000 .000 & 372.450 .000 & 370.228 .600 \\
\hline August & 413.200 .000 & 372.250 .000 & 365.118 .600 \\
\hline September & 312.700 .000 & 436.550 .000 & 833.470 .000 \\
\hline October & 492.200 .000 & 492.200 .000 & 457.350 .000 \\
\hline November & 432.200 .000 & 525.550 .000 & 659.350 .000 \\
\hline December & 432.200 .000 & 420.900 .000 & 659.350 .000 \\
\hline Total & 5.569 .400 .000 & 6.133 .725 .000 & 5.849 .858 .800 \\
\hline
\end{tabular}


Table 2. Revenue Sharing Income of BMT Al-Fath Ciputat in 2014-2016 (in IDR)

\begin{tabular}{|c|c|c|c|}
\hline Month & 2016 & 2015 & 2014 \\
\hline January & 0 & 1007500 & 8906600 \\
\hline February & 9289080 & 0 & 1258000 \\
\hline March & 0 & 9827424 & 9064434 \\
\hline April & 0 & 17443600 & 0 \\
\hline Mei & 3885216 & 14225000 & 0 \\
\hline June & 0 & 15166475 & 12676750 \\
\hline July & 0 & 0 & 20263166 \\
\hline August & 10000000 & 0 & 1554400 \\
\hline September & 15664318 & 0 & 6087500 \\
\hline October & 777500 & 0 & 1725000 \\
\hline November & 0 & 3899840 & 1238822 \\
\hline December & 1014000 & 0 & 6450000 \\
\hline Total & 40630114 & 61569839 & 77975089 \\
\hline
\end{tabular}

The total mudharabah financing value in 2014 amounted to IDR 5,849,858,800.00, in 2015 reached to IDR $6,133,725,000.00$, and in 2016 reached to IDR 5,569,400,000.00. By looking at the total amount of overall financing per year, it can be concluded that there is an increase in 2014 to 2015, but it shows a decline from 2015 to 2016 .

\section{Analysis of Mudharabah Revenue Sharing}

The following table shows the revenue sharing data of BMT Al-Fath Ikmi Ciputat for the last three years, from 2014 to 2016.

From the above data, it can be seen that the amount of BMT revenue income from mudharabah financing in 2014 amounted to IDR 77,975,089.00, in 2015 reached up to IDR
$61,569,839.00$, and the revenue in 2016 was IDR $40,630,114.00$. Therefore, it can be concluded that there is a decrease in revenue sharing of BMT from mudharabah financing provided to its clients every year.

The influence of Revenue-Sharing Income from Mudharabah Financing of BMT Al-Fath IKMI Ciputat

\section{Entered or Removed Variable}

All data used in this analysis are secondary data. This research aims to analyze the effect of revenue sharing for mudharabah financing in BMT Al-Fath Ikmi Ciputat by using simple linear regression method and IBM SPSS Statistics V.22.

Table 3. Entered or Removed Variable

\begin{tabular}{|c|c|c|c|}
\hline \multicolumn{4}{|c|}{ Variables Entered/Removed ${ }^{\mathrm{a}}$} \\
\hline Model & Variables Entered & $\begin{array}{l}\text { Variables } \\
\text { Removed }\end{array}$ & Method \\
\hline 1 & LN_financing ${ }^{\mathrm{b}}$ & & Enter \\
\hline \multicolumn{4}{|c|}{ a. Dependent Variable: LN_income } \\
\hline \multicolumn{4}{|c|}{ b. All requested variables entered. } \\
\hline
\end{tabular}

Source: analysis result of SPSS V.22 data

Table 4. Coefficient of Determination

\begin{tabular}{lccccc}
\hline \multicolumn{6}{c}{ Model Summary $^{\mathbf{b}}$} \\
\hline Model & $\mathrm{R}$ & R Square & $\begin{array}{c}\text { Adjusted R } \\
\text { Square }\end{array}$ & $\begin{array}{c}\text { Std. Error of the } \\
\text { Estimate }\end{array}$ & $\begin{array}{c}\text { Durbin- } \\
\text { Watson }\end{array}$ \\
\hline 1 &, $487^{\mathrm{a}}$ &, 237 &, 205 & 1,14660 & 1,930 \\
\hline a. Predictors: (Constant), LN_pembiayaan \\
b. Dependent Variable: LN_pendapatan
\end{tabular}


To find out the extent to which the effect of revenue-sharing from mudharabah financing, it can be done by performing analysis of entered variable and removed variable, as described in Table 3.3.

On entered or removed variables in Table 3.3., it appears that the variables included or used are mudharabah financing variables (X) as independent variable in order to see its effect on the dependent variable, which is revenue sharing. Assessment of Coefficient of Determination

This method is calculation to determine that the proportion within the variable that is explained by independent variable and therefore it will provide the degree to which variants in a variable have influence on other variables. This could be explained in Table 3.4.

To calculate the effect of mudharabah financing $(\mathrm{X})$ on the rise and fall of revenuesharing (Y), the researchers use coefficient of determination or determinant by looking at the above SPSS output table.

Based on the SPSS table above, the correlation coefficient in the calculation of SPSS is 0.487 . This means that the amount of mudharabah financing (X) has a positive and strong relationship. It is considered as positive relationship because that if the mudharabah financing increases, the BMT revenue-sharing income will increase; and on the contrary, if the mudharabah financing decreases, the BMT revenue sharing will decrease.

The coefficient of determination $(\mathrm{r} 2 / \mathrm{R}$ Square) is $0.237=23.7 \%$, which means that the revenue-sharing income of BMT (Y) can be explained by the mudharabah financing (X) is $23.7 \%$. On the other hand, the rest, which is $76.3 \%$, can be explained by other factors such as deposit products, other financing products such as include murabahah, qardul hasan, and others.

\section{Coefficient of Regression}

After analyzing the determinant coefficient, then the author will continue with the coefficient of regression to find out more about revenuesharing income of BMT from mudharabah financing.

Constant number (a) is a number indicating mudharabah financing before any effect on profit sharing of BMT.

The general form of a simple linear regression equation is

$$
\mathrm{Y}=\mathrm{a}+\mathrm{bX}
$$

where:

$\mathrm{Y}=$ Revenue-sharing income of BMT

$\mathrm{X}=$ Mudharabah financing

$\mathrm{a}=$ Constant, which is the value of $\mathrm{Y}$ if $\mathrm{X}=0$

$\mathrm{b}=$ Coefficient of regression, which is the change of $Y$ if $X$ changes one unit

Table 5. Regression of Mudharabah Financing

\begin{tabular}{|c|c|c|c|c|c|c|}
\hline \multicolumn{7}{|c|}{ Coefficients ${ }^{\mathbf{a}}$} \\
\hline \multirow[t]{2}{*}{ Model } & \multirow{2}{*}{ B } & \multicolumn{2}{|c|}{$\begin{array}{l}\text { Unstandardized } \\
\text { Coefficients }\end{array}$} & \multirow[t]{2}{*}{$\begin{array}{c}\text { Standardized } \\
\text { Coefficients }\end{array}$} & \multirow{2}{*}{$\mathrm{T}$} & \multirow{2}{*}{ Sig. } \\
\hline & & $\begin{array}{l}\text { Std. } \\
\text { Error }\end{array}$ & Beta & & & \\
\hline \multirow{2}{*}{1} & (Constant) & 3.793 & 5.520 & & .687 & .499 \\
\hline & LN_financing & .593 & .274 & .419 & 2.165 & .042 \\
\hline
\end{tabular}

a. Dependent Variable: LN_income

Source: analysis result of SPSS V.22 data

Based on the results of print out of SPSS calculations as seen in the table above, it we can determine that the regression equation is $\mathrm{Y}=$ $3793000+0.593$ (mudharabah financing) is equal to $\mathrm{Y}=3793000+0.593 \mathrm{X}$, which means that

$\mathrm{a}=3793000$, which means that if $\mathrm{X}=0$ or there is no mudharabah financing, the revenuesharing income (Y) is 3793000. $\mathrm{b}=$ the result of regression coefficient is 0.593 , which means that any increase of mudharabah financing, either in dozen or unit, will increase revenue sharing of 0.593 or every decrease suffered by mudharabah financing will decrease the revenue-sharing income by 0.593 . For example, the mudharabah financing in January 2014 was IDR 72633600 , in which the revenue-sharing income 
will rise by 0.593 . Therefore, the revenue sharing for BMT Al-Fath Ikmi Ciputat will increase by IDR 43071724.8. If mudharabah financing has increased, the profit sharing will also increase.

\section{Analysis of Hypothesis Testing}

Hypothesis testing is used to see whether or not the independent variable, which is mudharabah financing (X1), has significant correlation and influence on revenue-sharing income.

\section{t Statistic Test}

In this study, the $t$ test is used to assess the data whether there is a significant partial effect of the independent variable $(\mathrm{X})$ with the dependent variable (Y), which is revenue-sharing income. To find out the t-value of table statistics, a significant level of $5 \%(0.05)$ with degrees of freedom $\mathrm{df}$ $=(n-k-1)$ is determined, in which $\mathrm{n}=$ number of observations and $\mathrm{k}=$ number of variables.

The result of $t$ statistic test (partial test) found by using IBM SPSS Statistics V.22 can be seen in the following table.

Table 6. Result of Partial t Test

\begin{tabular}{|c|c|c|c|c|c|c|}
\hline \multicolumn{7}{|c|}{ Coefficients $^{\mathrm{a}}$} \\
\hline & \multirow{2}{*}{$\begin{array}{c}\text { Model } \\
\text { B }\end{array}$} & \multicolumn{2}{|c|}{$\begin{array}{l}\text { Unstandardized } \\
\text { Coefficients }\end{array}$} & \multirow[t]{2}{*}{$\begin{array}{l}\text { Standardized } \\
\text { Coefficients }\end{array}$} & \multirow{2}{*}{$\mathbf{T}$} & \multirow{2}{*}{ Sig. } \\
\hline & & $\begin{array}{l}\text { Std. } \\
\text { Error }\end{array}$ & Beta & & & \\
\hline \multirow{2}{*}{1} & (Constant) & 3,793 & 5,520 & & ,687 & ,499 \\
\hline & LN_pembiayaan & ,593 & ,274 & ,419 & 2,165 & ,042 \\
\hline
\end{tabular}

Based on the above output result acquired through SPSS V.22, we can conclude that:

Partial testing is conducted by $t$ statistic test to examine whether revenue-sharing income variable has significant influence on mudharabah financing.

From the results of the calculation of the $t$ test above, it can be seen that $\mathrm{t}_{\text {count }}<\mathrm{t}_{\text {table }}(0.687<$ 2.0322) with a significant value of the Mudharabah Financing variable is 0.499 , greater than 0.05 or $5 \%$ and has a positive coefficient direction.
It can be concluded that Ho is accepted and $\mathrm{Ha}$ is rejected, which means that the Mudharabah Financing variable does not have a significant effect on revenue-sharing income.

\section{F Statistic Test}

$F$ test is a model feasibility test, whether the simple linear regression model proposed is a feasible model to test the effect of independent variables on the dependent variable simultaneously.

Table 3.7. F Statistic Test

\begin{tabular}{|c|c|c|c|c|c|c|}
\hline \multicolumn{7}{|c|}{ ANOVA $^{\mathrm{a}}$} \\
\hline & Model & $\begin{array}{l}\text { Sum of } \\
\text { Squares }\end{array}$ & Df & Mean Square & $\mathbf{F}$ & Sig. \\
\hline \multirow{3}{*}{1} & Regression & 6,067 & 1 & 6,067 & 4,686 &, $042^{\mathrm{b}}$ \\
\hline & Residual & 28,484 & 22 & 1,295 & & \\
\hline & Total & 34,551 & 23 & & & \\
\hline
\end{tabular}

a. Dependent Variable: LN_income

b. Predictors: (Constant), LN_financing 
Based on the print out of ANOVA table above, it is also called as F statistical test. To test the hypothesis whether revenue-sharing income can be influenced by mudharabah financing by comparing the significance value of 0.045 with 0.05 . As seen in the table, the results are 0.045 $<0.05$, Ho is rejected and Ha is accepted meaning, which means that the independent variables of mudharabah financing simultaneously have significant effect on the dependent variable, namely revenue-sharing income.

\section{Classical Assumption Test Analysis Normality Test}

All the data used to analyze a problem must be tested for validity. In order to qualify for validity, a model can be tested by meeting the classical morality assumption conditions by using the Normal Probability Plot. The normality test is to see whether or not the residual value is normally distributed. A good regression model is to have residual values that are normally distributed. This is explained in figure 3.1 .

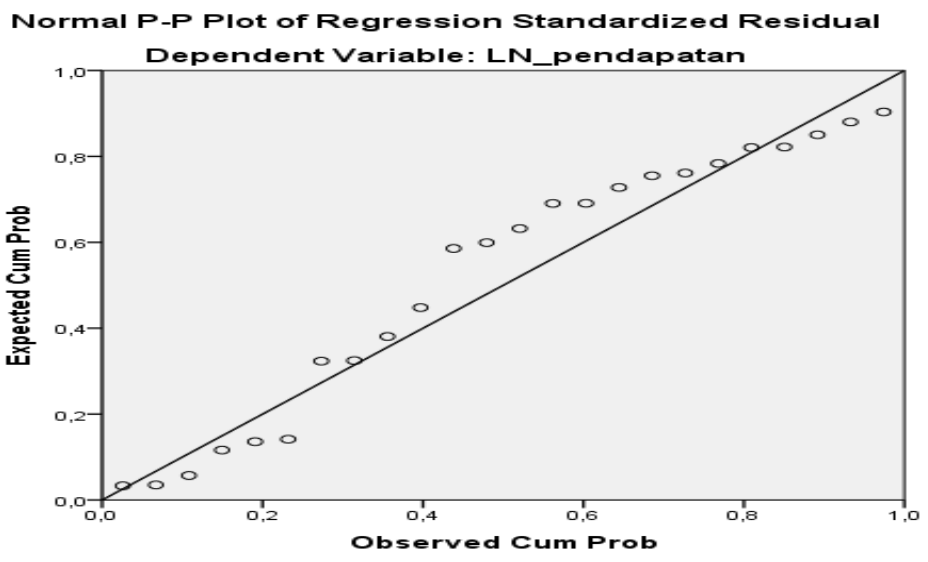

Source: analysis result of SPSS V.22 data

Figure 3.1. Normality Test

In principle, normality can be detected by seeing the spread of data (dots) on the diagonal axis from the graph above. It can be seen that the data spreads around the diagonal line and follows the direction of the diagonal line, which means the regression model meets the normality assumption and the data is normally distributed.

\section{Heteroscedasticity Test}

The heteroscedasticity test is conducted to see whether there is an inequality in the regression function. Heteroscedasticity testers can be detected by looking at the scatterplot from its SPSS output in Figure 3.2. below.

Scatterplot

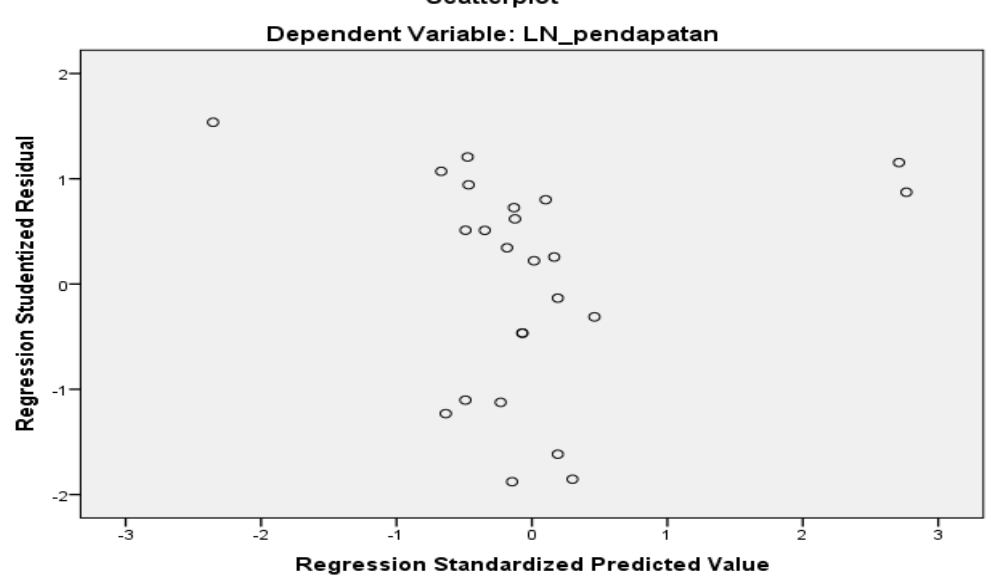

Source: analysis result of SPSS V.22 data

Figure 3.2. Heteroscedasticity Test 
From the scatterplot graphs that we can see in the picture above, the points spread randomly and spread both on the top and below number 0 on the $\mathrm{Y}$ axis. It can be concluded that there is no heteroscedasticity in the regression model, so the regression model is feasible to perform testing.

\section{Autocorrelation Test}

The autocorrelation test is conducted by Durbin Watson test (DW-Test). In order to detect the existence of autocorrelation, the researcher could perform Durbin-Watson statistic test, which is explained in Table 3.8.

Table 3.8. Autocorrelation Test

\begin{tabular}{lrrrrr}
\hline \multicolumn{5}{c}{ Summary $^{\mathbf{b}}$ Model } \\
\hline Model & R & R Square & $\begin{array}{l}\text { Adjusted R } \\
\text { Square }\end{array}$ & $\begin{array}{l}\text { Std. Error of } \\
\text { the Estimate }\end{array}$ & Durbin-Watson \\
\hline 1 &, $419^{\mathrm{a}}$ &, 176 &, 138 & 1,13786 & 2,022 \\
\hline $\begin{array}{l}\text { a. Predictors: (Constant), LN_financing } \\
\text { b. Dependent Variable: LN_income }\end{array}$ & & & \\
\hline
\end{tabular}

Source: analysis result of SPSS V.22 data

Based on the results of the Durbin-Watson test in the table above, it can be seen that the autocorrelation test on the Durbin-Watson test shows a value of 2.022 , in which the number is between -2 to +2 or $-2 \leq 2.022 \leq+2$. Therefore, it can be concluded that the data in this study is free from autocorrelation.

\section{Conclusion}

Based on the analysis, discussion, and previous explanation on the analysis of revenue sharing income from mudharabah financing of BMT AL-Fath Ikmi Ciputat, the researchers could make these conclusions:

a. The processed SPSS data shows that this study has the result of determination coefficient ( $\mathrm{r} 2$ / R Square) or its determination coefficient of $23.7 \%$. While the rest equals to $76.3 \%$ can be explained by other factors. The obtained regression equation is $\mathrm{Y}=3793000+0.593 \mathrm{X}$, which means: (a) $=a$ constant of 3793000 that is if $\mathrm{X}=0$ or if there is no mudharabah financing, then the revenue sharing income $(\mathrm{Y})$ is $3793000 ;(b)=$ regression coefficient of 0.593 indicates that if $\mathrm{X}$ or mudharabah financing is one unit, the revenue-sharing income or variable $\mathrm{Y}$ will rise by 0.593 .

b. Then, based on calculations with the $t$ test and statistical $\mathrm{f}$ test, the results of the second test results are smaller than the significant value of $0.687<2.0322$, then Ho is rejected and $\mathrm{Ha}$ is accepted. This states that the independent variable (mudharabah financing) is tested separately or together has an influence on the independent variable namely revenue sharing income.

c. The overall results of classical assumption testing, the data being processed are mudharabah financing data and revenuesharing income are normally distributed and have no problem on heteroscedasticity and autocorrelation test.

Based on the above conclusion, the researchers would like to give some suggestions that might be advantageous for sharia institution, such as:

a. BMT Al-Fath Ikmi Ciputat should be able to maintain or, even better, if it can increase the financing activities that have been implemented properly in order to increase revenue sharing.

b. In order to expand target market, BMT AlFath Ikmi Ciputat should conduct more promotional activities or socialization to the community directly or indirectly on an ongoing basis through mass media and religious store. This is to further introduce products produced according to sharia to the public, which will attract more prospective members.

\section{References}

Soemitra, Andri. 2010. Bank dan Lembaga keuangan syariah. Jakarta:

Prenadamedia group

Mardani. 2012. Fiqh Ekonomi Syariah. Jakarta: Prenadamedia group 
Muhammadiyah International Journal of Economics and Bussiness, Volume 1, Number 1, June 2018

Kasmir. 2010.Bank dan Lembaga keuangan lainnya, Jakarta: Rajawali Pers

Dahlan Siamat. 2010.Manajemen Lembaga Keuangan, Jakarta: Lembaga Penerbit FE UI

Nanang Martono. 2010. Metode Penelitian Kuantitatif: Analisa isi dan Analisis datasekunder.Jakarta.RajaGrafindoPersada

Sunaryo. 2009. Hukum Lembaga Pembiayaan. Jakarta: Sinar Grafika

Zainul Arifin. 2005. Dasar-Dasar Manajemen Bank Syariah, Jakarta: Pustaka Alvabet

M.NurAl Arif. 2010. Dasar-Dasar dan Pemasaran Bank Syariah, Bandung: Avabeta

Muhammad Syafi'i Antonio. 2010. Bank Syariah Dari Teori Ke Praktek, Jakarta: G e m a Insani Press
Arif, M.Nur Rianto. 2010. Dasar-Dasar Pemasaran Bank Syariah. Bandung: Alyabeta

Veitzal Rifai, dkk. 2010. Bank and Finansial Institution Management. Jakarta: kencana

Sigit Triandaru, dkk. 2010. Bank dan Lembaga Keuangan Lain. Jakarta: Salemba empat

Wirdyaningsih. 2010. Bank dan Asuransi Islam Di Indonesia. Jakarta: Kencana P e nad a Media

Ety Rochayety, dkk. 2009. Metodologi Penelitian Bisnis dengan Aplikasi SPSS. Jakarta : Mitra Wacana Media

Adiwarman A. Karim. 2010. Bank Islam. Jakarta : PT. Raja Grafindo Persada 